\title{
Spectro-electrochemical studies on [Ru(TAP)2(dppz)]2+ - insights into the mechanism of its photosensitized oxidation of oligonucleotides
}

Article

Accepted Version

Keane, P. M., Tory, J., Towrie, M., Sazanowich, I. V., Cardin, C. J., Quinn, S. J., Hartl, F., Kelly, J. M. and Long, C. (2019) Spectro-electrochemical studies on [Ru(TAP)2(dppz)]2+ insights into the mechanism of its photosensitized oxidation of oligonucleotides. Inorganic Chemistry, 58 (1). pp. 663-671. ISSN 0020-1669 doi:

https://doi.org/10.1021/acs.inorgchem.8b02859 Available at https://centaur.reading.ac.uk/81480/

It is advisable to refer to the publisher's version if you intend to cite from the work. See Guidance on citing.

To link to this article DOI: http://dx.doi.org/10.1021/acs.inorgchem.8b02859

Publisher: American Chemical Society

All outputs in CentAUR are protected by Intellectual Property Rights law, including copyright law. Copyright and IPR is retained by the creators or other copyright holders. Terms and conditions for use of this material are defined in the End User Agreement. 


\section{www.reading.ac.uk/centaur}

\section{CentAUR}

Central Archive at the University of Reading

Reading's research outputs online 


\title{
Spectro-electrochemical Studies on $\left[\mathrm{Ru}(\mathrm{TAP})_{2}(\mathrm{dppz})\right]^{2+}$ - Insights into the Mechanism of its Photosensitized Oxidation of Oligonucleotides
}

\author{
Páraic M. Keane,a,b Joanne Tory, ${ }^{\mathrm{b}}$ Michael Towrie, ${ }^{\mathrm{c}}$ Igor V. Sazanovich, ${ }^{\mathrm{c}}$ Christine J. Cardin, ${ }^{\mathrm{b}}$ Susan J.

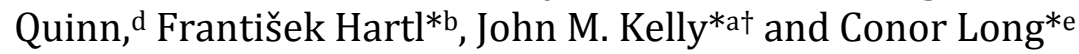

aSchool of Chemistry, University of Dublin, Trinity College, Dublin 2, Ireland; bDepartment of Chemistry, University of Reading, Whiteknights, Reading RG6 6AD, United Kingdom; 'Science and Technology Facilities Council, Rutherford Appleton Laboratory, Didcot, Oxfordshire, OX11 0QX, United Kingdom; dSchool of Chemistry, University College Dublin, Belfield, Dublin 4, Ireland; eSchool of Chemical Sciences, Dublin City University, Dublin 9, Ireland

†Corresponding author email jmkelly@tcd.ie

\begin{abstract}
Ru}(\mathrm{TAP})_{2}(\mathrm{dppz})\right]^{2+}(\mathrm{TAP}=1,4,5,8$-tetraazaphenanthrene; dppz = dipyrido[3,2-a:2',3'-c]phenazine) is known to photo-oxidize guanine in DNA. Whether this oxidation proceeds by direct photo-electron transfer or by proton-coupled electron transfer is still unknown. To help distinguish between these mechanisms, spectro-electrochemical experiments have been carried out with $\left[\mathrm{Ru}(\mathrm{TAP})_{2}(\mathrm{dppz})\right]^{2+}$ in acetonitrile. The UV/vis and mid-IR spectra obtained for the $1 \mathrm{e}^{-}$reduced product were compared to those obtained by picosecond transient absorption and time-resolved infrared experiments of $\left[\mathrm{Ru}(\mathrm{TAP})_{2}(\mathrm{dppz})\right]^{2+}$ bound to guanine-containing DNA. An interesting feature of the singly reduced species are electronic transitions in the near-IR region (with $\lambda_{\max }$ at 1970 and $2820 \mathrm{~nm}$ ). Density functional and time-dependent density functional theory simulations of the vibrational and electronic spectra of both $\left[\mathrm{Ru}(\mathrm{TAP})_{2}(\mathrm{dppz})\right]^{2+}$, the reduced complex $\left[\mathrm{Ru}(\mathrm{TAP})_{2}(\mathrm{dppz})\right]^{+}$and four isomers of $[\mathrm{Ru}(\mathrm{TAP})(\mathrm{TAPH})(\mathrm{dppz})]^{2+}$ (a possible product of proton-coupled electron transfer) were performed. Significantly these predict absorption bands at $\lambda>1900 \mathrm{~nm}$ (attributed to a ligand-to-metal charge-transfer transition) for $\left[\mathrm{Ru}(\mathrm{TAP})_{2}(\mathrm{dppz})\right]^{+}$but not for $[\mathrm{Ru}(\mathrm{TAP})(\mathrm{TAPH})(\mathrm{dppz})]^{2+}$. Both the UV/vis and mid-IR difference absorption spectra of the electrochemically generated singly reduced species $\left[\mathrm{Ru}(\mathrm{TAP})_{2}(\mathrm{dppz})\right]^{+}$agree well with the transient absorption and time-resolved infrared spectra previously determined for the transient species formed by photo-excitation of $\left[\mathrm{Ru}(\mathrm{TAP})_{2}(\mathrm{dppz})\right]^{2+}$ intercalated in guanine-containing DNA. This suggests that the photochemical process in DNA proceeds by photo-electron transfer and not by a proton-coupled electron transfer process involving formation of $[\mathrm{Ru}(\mathrm{TAP})(\mathrm{TAPH})(\mathrm{dppz})]^{2+}$, as is proposed for the reaction with $5^{\prime}$-GMP. Additional infrared spectroelectrochemical measurements and density functional calculations have also been carried out on the free TAP ligand. These show that the TAP radical anion in acetonitrile also exhibits strong broad near-IR electronic absorption $\left(\lambda_{\max }\right.$ at 1750 and $\left.2360 \mathrm{~nm}\right)$.
\end{abstract}

\section{Introduction}

The photosensitized oxidation of nucleic acids by metal complexes is attracting increasing attention in part because it offers a possible route to targeted methods for new therapies and diagnostics. ${ }^{1-6}$ One group of compounds which have been found to be particularly useful are ruthenium complexes containing two or three 1,4,5,8-tetraazaphenanthrene (TAP) ligands, which not only may cause strand breaks in DNA but also forms photo-adducts with guanine. . $^{-10}$

Through luminescence and nanosecond flash photolysis studies it has been definitively shown that the excited state of $\left[\mathrm{Ru}(\mathrm{TAP})_{2}(\mathrm{~L})\right]^{2+}$ (where $\mathrm{L}$ is a bidentate hetero-aromatic) is reduced by $5^{\prime}$-guanosine monophosphate (5'-GMP). ${ }^{7,} 10$ However the products observed at neutral $\mathrm{pH}$ or below are the protonated reduced species while the oxidized guanine is the guanine radical (equation 1). The presence of these proton-transfer products is not unexpected as the $\mathrm{p} K_{\mathrm{a}}$ for $\left[\mathrm{Ru}(\mathrm{TAP})_{2}(\mathrm{~L})\right]^{+}$compounds is generally greater than $7.5^{7,10}$ and that for the GMP radical cation is $3.9,{ }^{11}$ so that these species would be formed on the 
nanosecond time scale by protonation/deprotonation of the products formed by the direct photo-induced electron transfer (PET) (equation 2).

$$
\begin{array}{lllll}
{\left[\operatorname{Ru}(\mathrm{TAP})_{2}(\mathrm{~L})\right]^{2+*}} & + & \mathrm{G} & \rightarrow & {\left[\operatorname{Ru}(\mathrm{TAP})\left(\mathrm{TAPH}^{\bullet}\right)(\mathrm{L})\right]^{2+}+\mathrm{G}(-\mathrm{H})^{\bullet}} \\
{\left[\operatorname{Ru}(\mathrm{TAP})_{2}(\mathrm{~L})\right]^{2+*}} & + & \mathrm{G} & \rightarrow & {\left[\operatorname{Ru}(\mathrm{TAP})_{2}(\mathrm{~L})\right]^{+}+\mathrm{G}^{\bullet+}}
\end{array}
$$

Nanosecond flash photolysis studies of $\left[\operatorname{Ru}(T A P)_{2}(d p p z)\right]^{2+}$ with $5^{\prime}$-GMP showed that there is a kinetic isotope effect for both the forward (i.e. excited-state) reaction and the subsequent back reaction. ${ }^{12}$ and this was tentatively proposed to be a result of proton-coupled electron transfer (PCET) within the solvent cage. More recently a series of detailed photo-CIDNP (chemically induced dynamic nuclear polarization) studies of the reduction of various $\left[\mathrm{Ru}(\mathrm{TAP})_{2}(\mathrm{~L})\right]^{2+}$ with $5^{\prime}$-GMP and other reducing biomolecules have been reported by Kirsch-De Mesmaeker, Luhmer and coworkers. ${ }^{13-16}$ With 5'-GMP as quencher, strongly enhanced absorption signals are found, predominantly for the 2,7-TAP protons (much weaker for the 3,6TAP protons and absent for the 9,10-TAP protons) (see Figure 1 for the numbering of atoms in TAP), while a strong effect is also observed for the H8 of the GMP. This result is consistent with formation of the reduced metal complex and the oxidized nucleotide in the solvent cage; the CIDNP signal arises because of the competition between the back-electron transfer and the escape of the two radical species. However, it is still not clear from these studies whether the proton-transfer products are formed by a reaction within the solvent cage (i.e., PCET) or in the escape products of an initial PET process. Indeed, this is often a general question for photosensitized electron transfer with nucleotides.

In the case of double-stranded DNA it is preferable to investigate such photoredox processes with intercalators, as the geometry is then relatively well-defined. We have therefore studied $\left[\mathrm{Ru}(\mathrm{TAP})_{2}(\mathrm{dppz})\right]^{2+}$, as such dppz complexes are well known to insert the dppz ligand between the basepairs of double-stranded DNA. ${ }^{17,18}$ This has been confirmed recently by crystallography. ${ }^{19-25}$ Photoinduced reactions sensitized by such complexes are conveniently monitored by transient visible absorption (TA) and by time-resolved infra-red (TRIR) spectroscopy. ${ }^{25-30}$ Initial experiments, which were carried out with racemic samples and double-stranded polydGdC, demonstrated modest isotope effects for both the excited state and subsequent reverse reactions. ${ }^{26}$ This was interpreted as a possible PCET process but in this case with the isotope effect being as a result of proton-transfer within the G-C base pair, and not to formation of $[\mathrm{Ru}(\mathrm{TAP})(\mathrm{TAPH})(\mathrm{dppz})]^{2+}$ as expected for 5'-GMP.

$$
\left[\operatorname{Ru}(\mathrm{TAP})_{2}(\mathrm{dppz})\right]^{2+*}+\quad \mathrm{G}-\mathrm{C} \quad \rightarrow \quad\left[\mathrm{Ru}(\mathrm{TAP})_{2}(\mathrm{dppz})\right]^{+}+\left[\mathrm{G}(-\mathrm{H})^{\bullet} \ldots \mathrm{CH}\right]^{+}
$$

To help clarify the mechanism at work for the nucleotide or guanine-containing DNAs we have recorded the UV/vis, near-IR and mid-IR regions spectra of the reduced species $\left[\mathrm{Ru}(\mathrm{TAP})_{2}(\mathrm{dppz})\right]^{+}$after generating it electrochemically in acetonitrile. The spectra of the reduced species obtained are also compared to those simulated using density functional theory (DFT) and time-dependent density functional theory (TDDFT) methods for $\left[\mathrm{Ru}(\mathrm{TAP})_{2}(\mathrm{dppz})\right]^{+}$and several protonated isomers, $\left[\mathrm{Ru}(\mathrm{TAP})\left(\mathrm{TAPH} \mathrm{C}^{\bullet}(\mathrm{dppz})\right]^{2+}\right.$. Transient products arising from the interaction of the excited state with 5'-GMP are also investigated. Finally, the spectro-electrochemical data are compared to those obtained by both TA and TRIR from $\left[\mathrm{Ru}(\mathrm{TAP})_{2}(\mathrm{dppz})\right]^{2+}$ bound to an oligonucleotide, where the yield of electron transfer is particularly high. Spectro-electrochemical methods are increasingly finding applications for understanding the photophysical and photochemical behavior of ruthenium polypyridyl complexes which interact with DNA. ${ }^{31}$ 


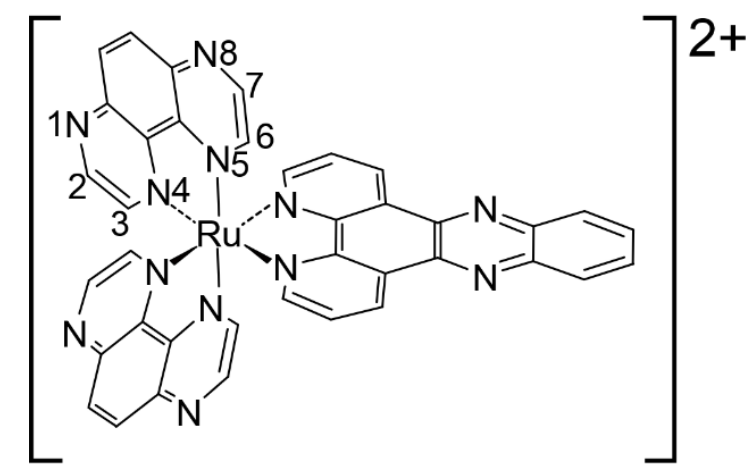

(1)

Figure 1. A pictorial representation of $\left[\operatorname{Ru}(\mathrm{TAP})_{2}(\mathrm{dppz})\right]^{2+}$ showing the TAP ring numbering system used and its orientation relative to the other ligands

Results and Discussion

\section{UV/vis Spectro-electrochemistry}

In line with the literature data, ${ }^{12}\left[\mathrm{Ru}(\mathrm{TAP})_{2}(\mathrm{dppz})\right]^{2+}\left(2 \times 10^{-3} \mathrm{M}\right)$ in acetonitrile/ $\mathrm{Bu}_{4} \mathrm{NPF}_{6}$ was found to undergo two reversible one-electron reductions at $-0.80 \mathrm{~V}$ and $-0.98 \mathrm{~V}$ vs SCE. The corresponding thinlayer cyclic voltammogram (TL-CV) recorded in the course of the UV/vis monitoring of these cathodic steps revealed a similar $(160-200 \mathrm{mV})$ potential separation of the corresponding cathodic waves (Supporting Information, Figure S1), The fully reversible nature of the initial one-electron reduction in acetonitrile- $d_{3} / \mathrm{KPF}_{6}$ was also confirmed by the corresponding TL-CV (Supporting Information, Figure S2).

The initial reduction of $\left[\operatorname{Ru}(\mathrm{TAP})_{2}(\mathrm{dppz})\right]^{2+}$ is accompanied by decreasing absorption of the parent complex at $414 \mathrm{~nm}$ (with a low-energy shoulder at $449 \mathrm{~nm}$ ) and the growth of new absorption of the mono-cation $\left[\mathrm{Ru}(\mathrm{TAP})_{2}(\mathrm{dppz})\right]^{+}$at $451 \mathrm{~nm}$ (Figure 2 (a)); this band also features several shoulders tailing to the lower energy region. Additionally, a new absorption band appears at $356 \mathrm{~nm}$. This UV absorption associated with the TAP ligand reduction continues to grow also during the second one-electron cathodic step, being slightly shifted to $342 \mathrm{~nm}$ (Figure 2 (b)). The product of the two-electron reduction $\left[\operatorname{Ru}(\mathrm{TAP})_{2}(\mathrm{dppz})\right]$ absorbs strongly in the visible region with two bands showing maxima at 489 and 579 $\mathrm{nm}$.

The reoxidation of the one-electron reduced species led to almost complete recovery of the parent electronic absorption. This near perfect reversibility (and the small peak-to-peak separation) is strong evidence that the process involves a simple one electron reduction. The reaction also proceeds without observable decomposition., so that the formation of free TAP ligand is negligible. The reoxidation of the two-electron reduction product, $\left[\mathrm{Ru}(\mathrm{TAP})_{2}(\mathrm{dppz})\right]$, also proceeds without decomposition, although at higher concentration (e.g. $5 \mathrm{mM}$ ) some precipitation of $\left[\mathrm{Ru}(\mathrm{TAP})_{2}(\mathrm{dppz})\right]$ was observed. 

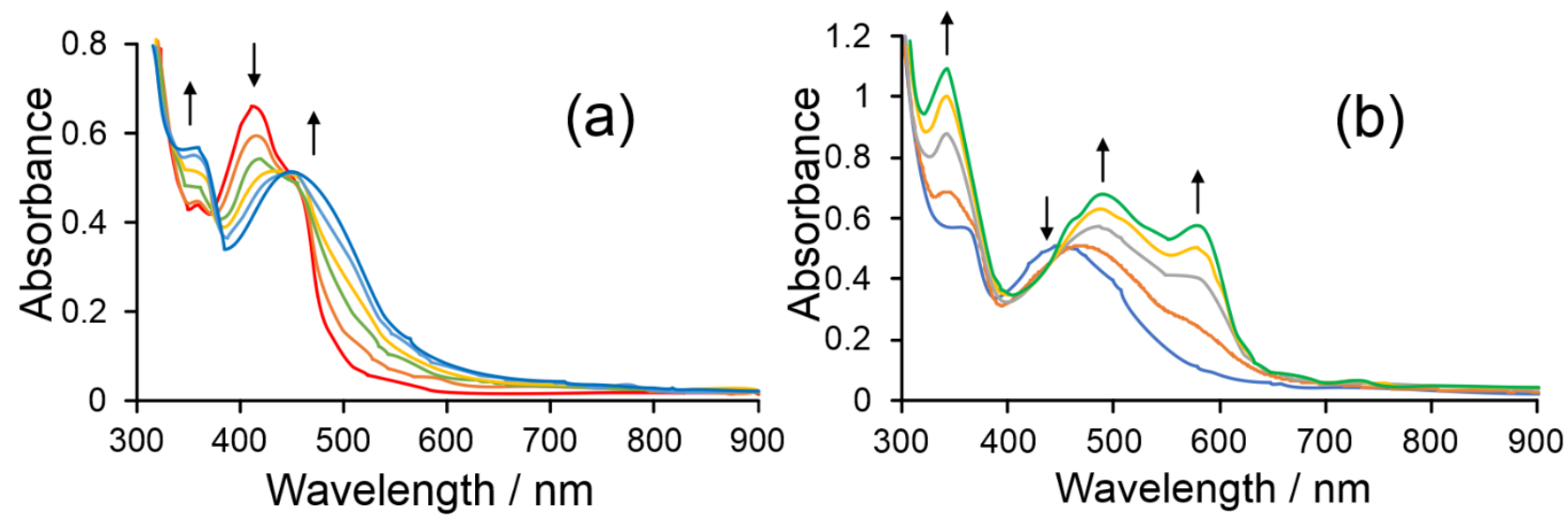

Figure 2. UV/vis spectro-electrochemistry within an OTTLE cell of (a) $2 \times 10^{-3} \mathrm{M}\left[\mathrm{Ru}(\mathrm{TAP})_{2}(\mathrm{dppz})\right]^{2+}$ in $\mathrm{CH}_{3} \mathrm{CN} / 0.3 \mathrm{M}$ $\mathrm{Bu}_{4} \mathrm{NPF}_{6}$ showing spectral changes accompanying the reversible initial one-electron reduction to [Ru(TAP) $\left.)_{2}(\mathrm{dppz})\right]^{+}$and (b) the subsequent further one-electron reduction to form neutral [Ru(TAP) $2(\mathrm{dppz})]$.

\section{DFT calculations on the electronic spectra of $\left[\operatorname{Ru}(\operatorname{TAP})_{2}(d p p z)\right]^{2+}(1)$ and $\left[\operatorname{Ru}(T A P)_{2}(d p p z)\right]^{+}$.}

DFT and TD-DFT methods were used to simulate the visible/near-IR spectra, of both $\left[\mathrm{Ru}(\mathrm{TAP})_{2}(\mathrm{dppz})\right]^{2+}$ and $\left[\operatorname{Ru}(\mathrm{TAP})_{2}(\mathrm{dppz})\right]^{+}$. The band structure was obtained by placing Gaussian functions $\left(3000 \mathrm{~cm}^{-1}\right.$ width at half height) at each of the vertical excitation energies to singlet excited states obtained in TD-DFT calculations. The resulting spectrum of $\left[\operatorname{Ru}(\mathrm{TAP})_{2}(\mathrm{dppz})\right]^{2+}$ is shown in Figure $3(\mathrm{~b})$, along with the vertical excitation energies to singlet states and electron density difference maps for significant states. The simulated spectrum is in excellent agreement with the experimental spectrum in acetonitrile solution (Figure 3 (a)). The electron density difference maps were constructed by subtracting the electron density of the ground state from that of selected excited states as indicated in the figure (orbital contributions for the other states are given in the Supporting Information Table S1).

These calculations suggest that the longest wavelength absorptions at 457, 441, and $424 \mathrm{~nm}(21890$, 22660 , and $23560 \mathrm{~cm}^{-1}$ ) are principally Ru-to-TAP charge-transfer in character, while the feature close to the observed maximum at $408 \mathrm{~nm}$ (calculated at $406 \mathrm{~nm}, 24,630 \mathrm{~cm}^{-1}$ ) has a greater Ru-to-dppz chargetransfer character. This is consistent with calculations reported previously ${ }^{32-35}$ and with resonance Raman measurements. ${ }^{36}$

Given the success of the TD-DFT method in simulating the absorption spectrum of the dication, the same procedure was used to model the UV/vis absorption spectrum of the singly reduced species, $\left[\mathrm{Ru}(\mathrm{TAP})_{2}(\mathrm{dppz})\right]^{+}$(Figure $3(\mathrm{~d})$ and Supporting Information Table S2). The electron spin density map for this mono-cation shows that the unpaired spin is localized on both TAP ligands (see Figure 3 (c)). Transitions in the visible region are predominantly Ru-to-TAP charge-transfer but with some Ru-to-dppz character. Importantly, the calculations also predict transitions in the near IR (for instance at $3655 \mathrm{~nm}$, oscillator strength $=0.034$ see Figure $3(d)$ ), which has substantial TAP-to-Ru charge-transfer character. 

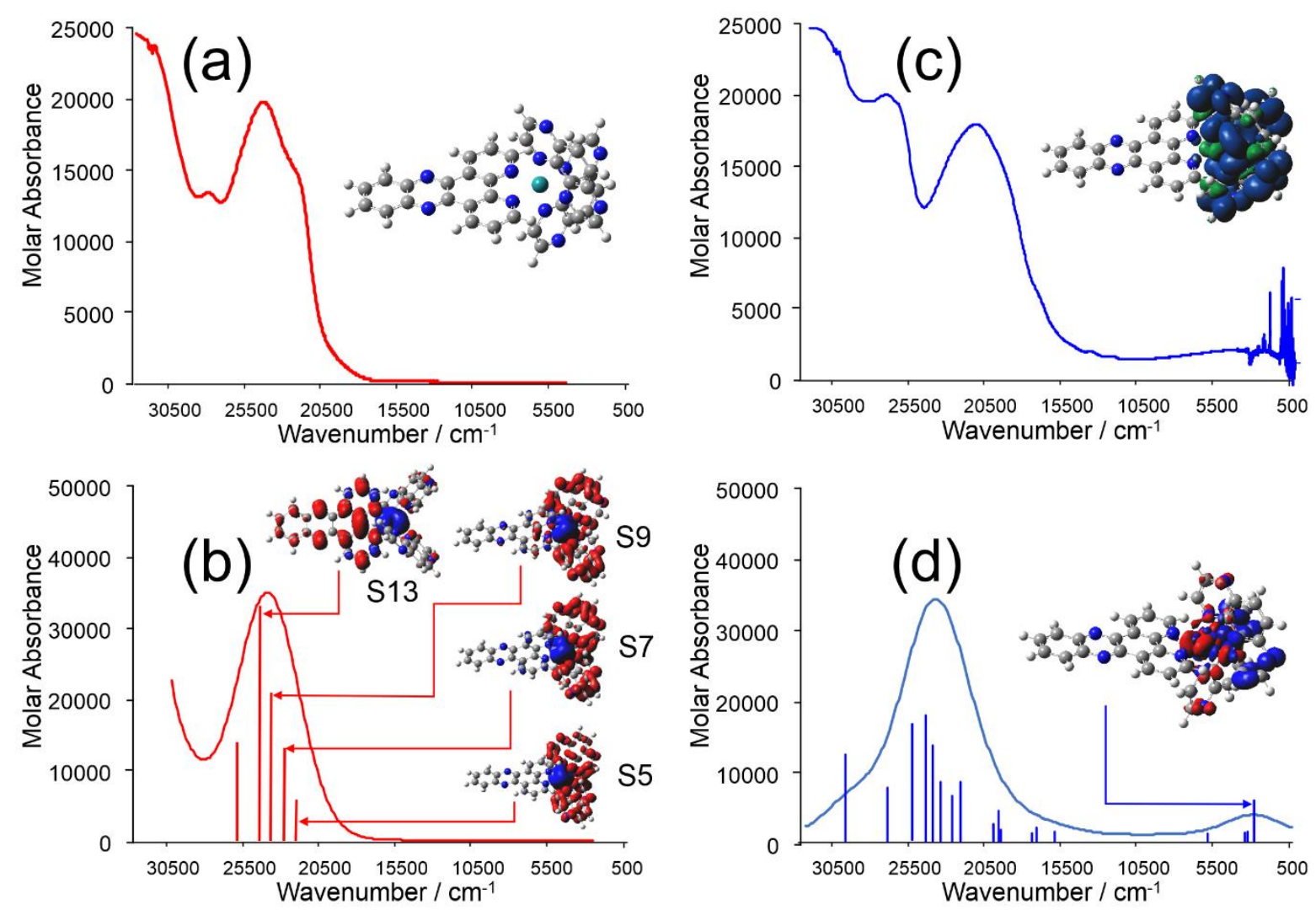

Figure 3. UV/vis/near-IR spectra; (a) experimental spectrum of $\left[\mathrm{Ru}(\mathrm{TAP})_{2}(\mathrm{dppz})\right]^{2+}$ in acetonitrile accompanied by a molecular model of the complex with the dppz ligand towards the left; (b) the simulated spectrum of $\left[\mathrm{Ru}(\mathrm{TAP}){ }_{2}(\mathrm{dppz})\right]^{2+}$ modelled in acetonitrile with the individual vertical excitations (red vertical lines) along with selected electron density difference maps of the main transitions. Red volumes indicate the regions of increased electron density in the excited state while blue regions are those of reduced electron density; (c) composite experimental spectrum of [Ru(TAP) 2 (dppz) $]^{+}$obtained by joining data obtained from near IR and FTIR experiments in acetonitrile generated electrochemically with the spin density map showing the location of the unpaired spin; (d) the simulated spectrum of [Ru(TAP) $\left.)_{2}(\mathrm{dppz})\right]^{+}$in acetonitrile showing the electron density difference map of the lowest-energy electronic transition.

\section{Infrared Spectro-electrochemistry}

The infrared spectrum of $\left[\operatorname{Ru}(\mathrm{TAP})_{2}(\mathrm{dppz})\right]^{2+}$ in the finger print region is populated by several ligandbased vibrations. IR spectro-electrochemical experiments focused on the initial one-electron reduction of $\left[\mathrm{Ru}(\mathrm{TAP})_{2}(\mathrm{dppz})\right]^{2+}$, monitoring in the range $500-7000 \mathrm{~cm}^{-1}$. These were carried out in an OTTLE cell (optical pathlength $=0.2 \mathrm{~mm}$ ) at a concentration of $1 \times 10^{-2} \mathrm{M}$ with a supporting electrolyte solution of 2 $\times 10^{-1} \mathrm{M} \mathrm{KPF}_{6}$ in dry acetonitrile- $d_{3}$. This experimental arrangement provided an IR spectral window fully transparent in the desired range of 1600 to $1200 \mathrm{~cm}^{-1}$, which was also previously probed in the TRIR experiments. ${ }^{37}$ The IR spectro-electrochemical reduction was also monitored in parallel with UV/vis detection and the observed spectral changes were consistent with those depicted in Figure 2 (a). The IR spectral changes in the fingerprint region accompanying the initial one-electron reduction step are presented in Figure 4 (a) and Supporting Information Table S3. Reversible reoxidation on the reverse scan is represented in the Figure S3 of the Supporting Information. The spectra exhibit clear isosbestic points indicating a single process uncomplicated by side or subsequent reactions. A prominent absorption feature of the reduced species is the broad band at $1455 \mathrm{~cm}^{-1}$. Similar results were obtained with solvent containing ca. $3 \times 10^{-1} \mathrm{M} \mathrm{H}_{2} \mathrm{O}$. 

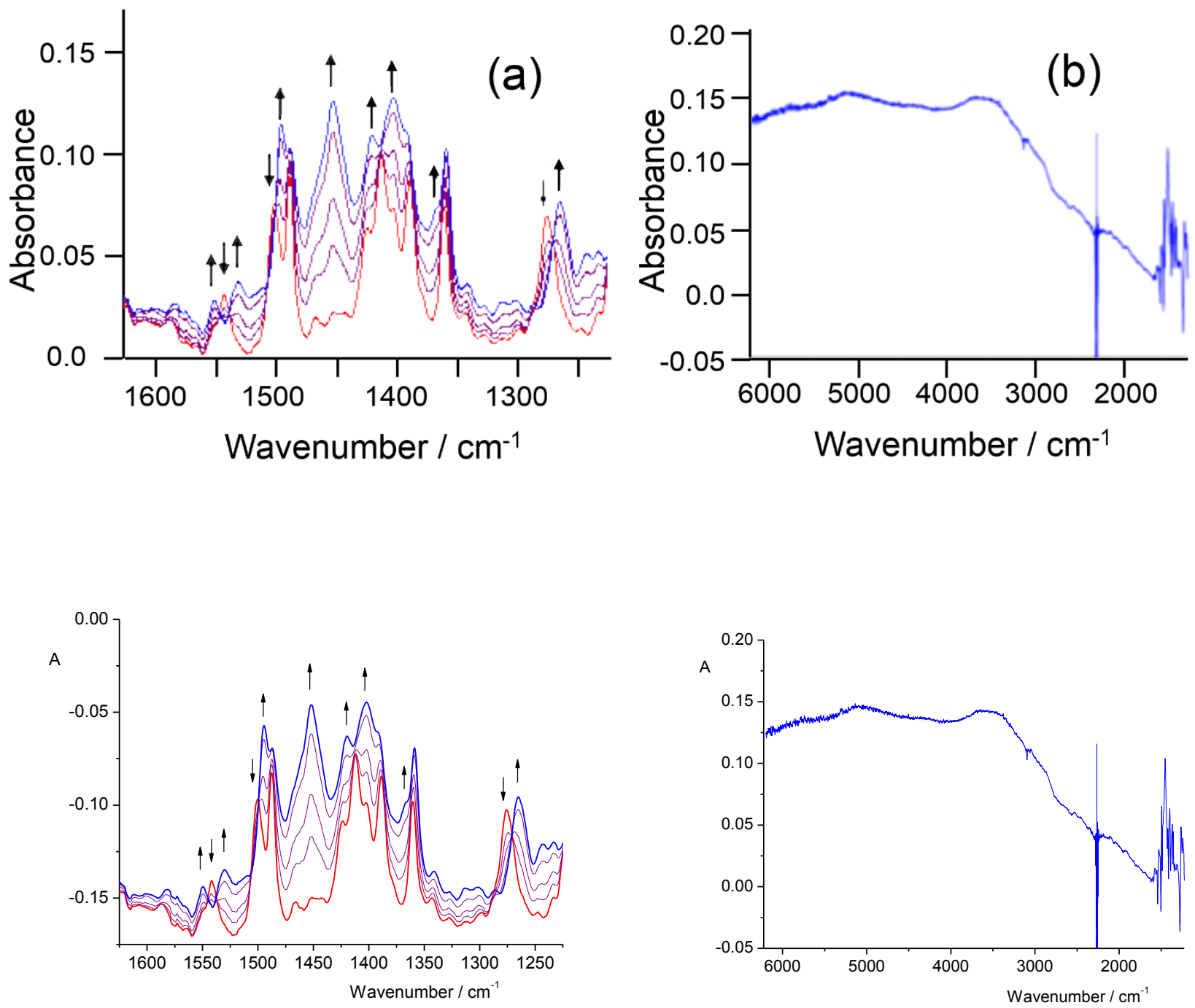

Figure 4. (a) IR spectro-electrochemistry of $1 \times 10^{-2} \mathrm{M}\left[\mathrm{Ru}(\mathrm{TAP})_{2}(\mathrm{dppz})\right]^{2+}$ in acetonitrile- $d_{3} / 2 \times 10^{-1} \mathrm{M} \mathrm{KPF} 6$ showing the initial $1 \mathrm{e}^{-}$reduction step within an OTTLE cell. The corresponding TL-CV is depicted in Figure S2 of the Supporting Information (b) the electronic absorption of $\left[\mathrm{Ru}(\mathrm{TAP})_{2}(\mathrm{dppz})\right]^{+}$in the NIR-IR region, with the invariable IR absorption bands removed.

When FTIR spectra were recorded at larger wavenumbers (up to $7000 \mathrm{~cm}^{-1}$ ), it was noted that the compound exhibited broad band absorption. (see Figure 4 (b)). This absorption was removed when the sample was re-oxidized (Figure S3 (b) in the Supporting Information), confirming that these near-IR bands are features of $\left[\mathrm{Ru}(\mathrm{TAP})_{2}(\mathrm{dppz})\right]^{+}$. By subtracting the vibrational components, the spectroscopic behavior of the electronic transition is revealed. Absorption maxima occur at 3540, 4320, 5080 and 5750 $\mathrm{cm}^{-1}(2820,2310,1970$ and $1740 \mathrm{~nm})$. The molar absorptivity at $3540 \mathrm{~cm}^{-1}$ is ca. $650 \mathrm{M}^{-1} \mathrm{~cm}^{-1}$. The presence of these electronic absorption bands was further confirmed by recording the spectra on a nearIR spectrophotometer (Figure 3 (c)) shows this spectrum combined with that obtained by FTIR).

To investigate whether any of the mid- and near-IR spectroscopic features observed for the reduced species $\left[\mathrm{Ru}(\mathrm{TAP})_{2}(\mathrm{dppz})\right]^{+}$are produced by TAP ${ }^{-}$, the behavior of the free TAP $(1,4,5,8$-tetraazaphenanthrene) ligand was investigated by spectro-electrochemical methods (UV/vis monitoring of this reduction process was reported previously ${ }^{38}$ ). Figure 5 shows the near-IR and mid-IR absorption spectra 
obtained. Strikingly the reduced compound shows broad absorption bands $\left(\tilde{v}_{\max }=5720\right.$ and $4230 \mathrm{~cm}^{-}$ ${ }^{1}$ ). The IR absorption spectra also show a very strong band at $716 \mathrm{~cm}^{-1}$ for the reduced species (see Supporting Information Figure S4). In the mid-IR a broad feature is evident between 1400 and $1500 \mathrm{~cm}^{-}$ ${ }^{1}$. This might arise either from a low-lying electronic transition or possibly it is an overtone of the $716 \mathrm{~cm}^{-}$ ${ }^{1}$ feature.
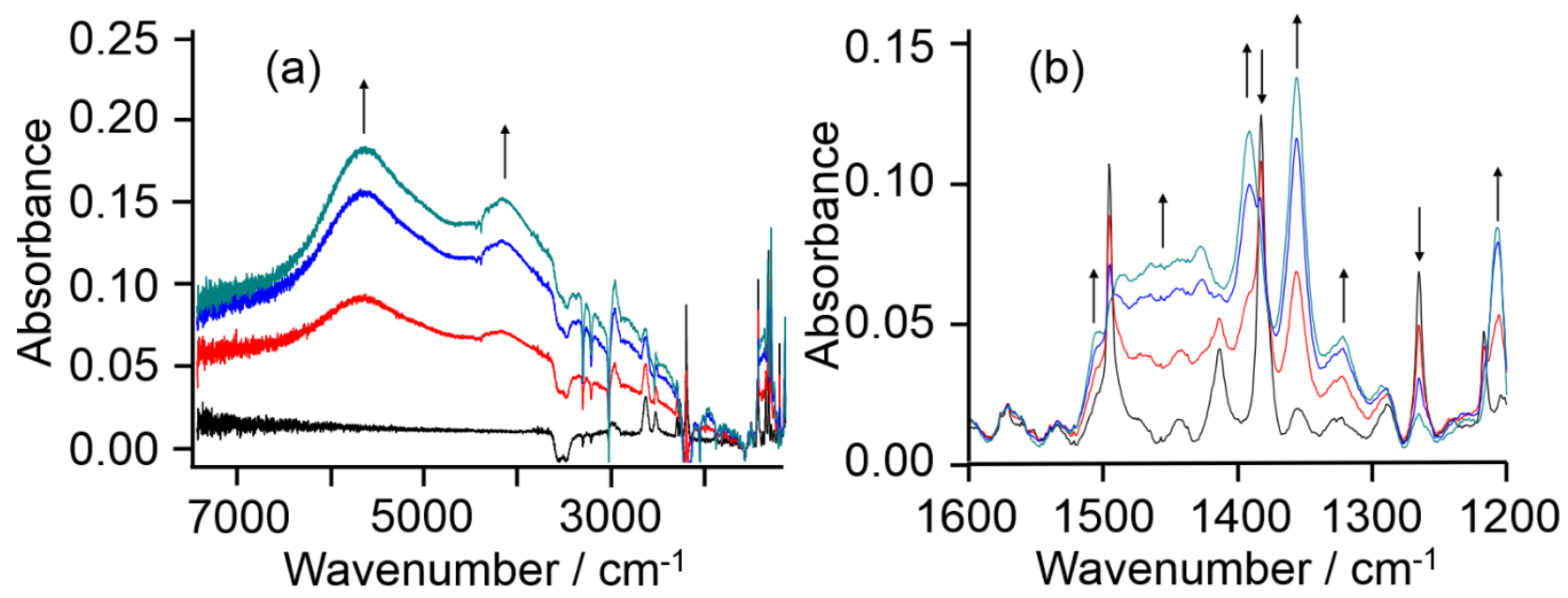

Figure 5. (a) Near-IR and (b) Mid-IR spectra generated by $1 \mathrm{e}^{-}$reduction of $3.5 \times 10^{-2} \mathrm{M}$ 1,4,5,8-tetraazaphenanthrene (TAP) in acetonitrile- $d_{3} / \mathrm{KPF}_{6}$ within an OTTLE cell conducted at the first (reversible) cathodic wave. (Note that the radical anion of TAP shows a weak electronic absorption also in this fingerprint IR region.)

\section{DFT calculations on the vibrational spectra of $\left[\operatorname{Ru}(T A P)_{2}(d p p z)\right]^{2+}(1)$ and $\left[\operatorname{Ru}(T A P)_{2}(d p p z)\right]^{+}$.}

Simulations of the IR spectra for the $\left[\operatorname{Ru}(\mathrm{TAP})_{2}(\mathrm{dppz})\right]^{2+}$ and $\left[\mathrm{Ru}(\mathrm{TAP})_{2}(\mathrm{dppz})\right]^{+}$species were also attempted using a wide arrange of hybrid and pure density functionals, (see experimental for details and Figure S5 and Figure S6). The hybrid functional B3LYP performed best in replicating the experimental spectrum of $\left[\mathrm{Ru}(\mathrm{TAP})_{2}(\mathrm{dppz})\right]^{2+}$. As can be seen in Figure 6 (a), the main features in the $1600-1200$ $\mathrm{cm}^{-1}$ region for $\left[\mathrm{Ru}(\mathrm{TAP})_{2}(\mathrm{dppz})\right]^{2+}$ are well reproduced. 

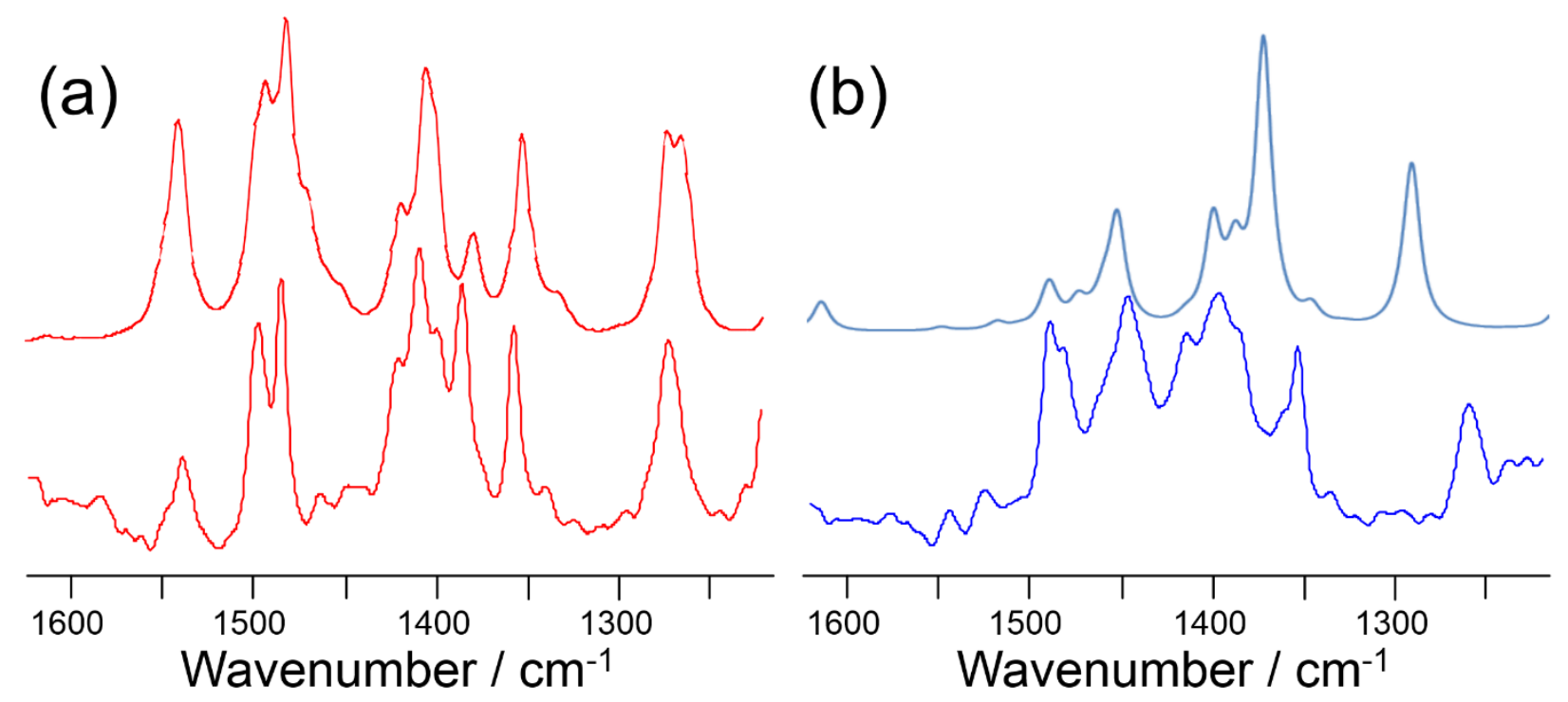

Figure 6. (a) A comparison of the calculated spectrum of $\left[\mathrm{Ru}(\mathrm{TAP})_{2}(\mathrm{dppz})\right]^{2+}(\mathbf{1})$ in acetonitrile (upper) with the experimental spectrum (lower); (b) the experimental spectrum of the singly reduced [Ru(TAP) $\left.{ }_{2}(\mathrm{dppz})\right]^{+}$(see Figure 4) species (lower) and its simulated spectrum (upper).

The IR absorption spectrum for $\left[\mathrm{Ru}(\mathrm{TAP})_{2}(\mathrm{dppz})\right]^{+}$in the same range was also simulated (Figure 6 (b)). Again, B3LYP performed best. While many of the features in the experimental spectrum are reproduced in the simulation, the agreement was less good than for $\left[\mathrm{Ru}(\mathrm{TAP})_{2}(\mathrm{dppz})\right]^{2+}$. Therefore to probe whether better agreement with experiment might be possible, and guided by recent papers on the excited states of ruthenium polypyridyls, ${ }^{39-40}$ we have examined the effect of stretching the $\mathrm{Ru}-\mathrm{N}$ bonds, both $\mathrm{Ru}-\mathrm{TAP}$ and $\mathrm{Ru}-\mathrm{dppz}$, looking for additional local minima in the potential energy surface. Such local minima were located in these calculations and Figure 7 presents the simulated IR spectra for these two valence bond isomers, dubbed $1^{\text {st }}$ and $2^{\text {nd }}$ minima, formed by stretching the Ru-dppz and Ru-TAP bonds (see Supporting Information Table S4 for optimized Ru-N bond distances and spin density maps at these minima). Most conspicuous is the appearance of structured absorptions in the 1380 to $1430 \mathrm{~cm}^{-1}$ region in the simulated IR spectra in these local minima for the Ru-dppz species, where a prominent broad feature is also observed in the experimental spectrum. (However additional bands also appear in the 1430 to 1480 $\mathrm{cm}^{-1}$ region which are absent in the experimental spectrum) 

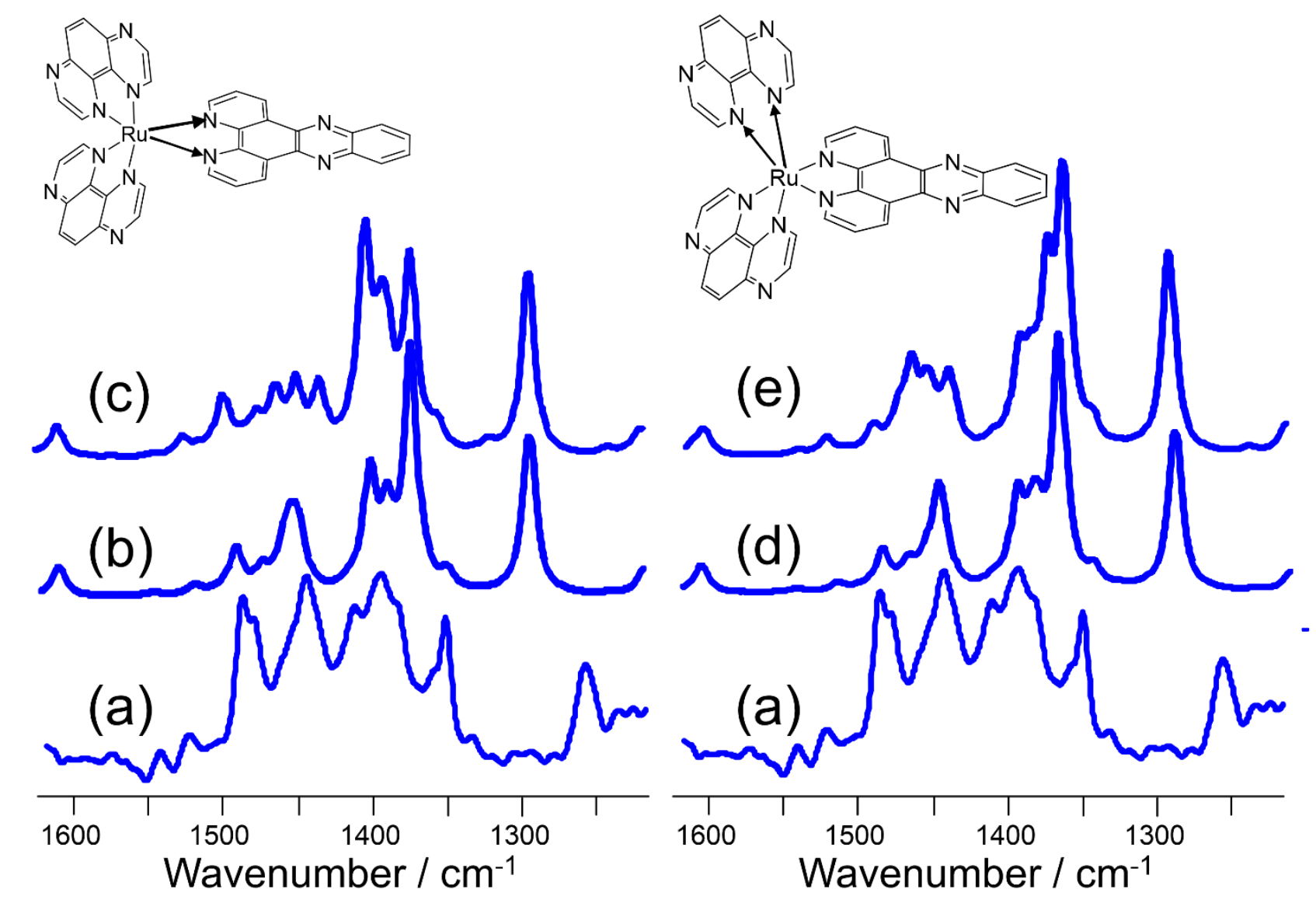

Figure 7. A comparison of (a) the experimental IR absorption spectrum of $\left[\mathrm{Ru}(\mathrm{TAP})_{2}(\mathrm{dppz})\right]^{+}$and the simulated spectrum calculated using for the first (b) and second local minima (c) located following a Ru to dppz relaxed potential energy scan and the first (d) and second (e) minima of the relaxed Ru-to-TAP potential energy scan as indicated by the arrows.

It is important to note that the simulated spectra presented here represent the fundamental transitions only. Experimental spectra will also contain overtone and combination bands. These may be significant especially in systems with asymmetric charge distribution, resulting in resonance or dipole enhancement of some fundamental absorptions, with concomitant increases to the associated overtone and combination bands. For instance, the calculated spectrum of $\left[\mathrm{Ru}(\mathrm{TAP})_{2}(\mathrm{dppz})\right]^{+}$exhibits an exceptionally strong dipole-enhanced ring-breathing mode at $830 \mathrm{~cm}^{-1}$. It is possible that an overtone or combination of this band appears in the $1400-1600 \mathrm{~cm}^{-1}$ region. As noted above, a similar strong feature (at $710 \mathrm{~cm}^{-1}$ ) is present in the measured spectrum of the singly reduced 1,4,5,8-tetraazaphenanthrene.

In conclusion while these simulations of the IR spectrum of $\left[\operatorname{Ru}(\mathrm{TAP})_{2}(\mathrm{dppz})\right]^{+}$are not as good as that found with $\left[\mathrm{Ru}(\mathrm{TAP})_{2}(\mathrm{dppz})\right]^{2+}$ the major features are well represented by using the B3LYP functional. In particular, the appearance of a strong band at about $1460 \mathrm{~cm}^{-1}$ in the reduced complex is significant, as it is the dominant feature in the TRIR spectrum recorded for the complex bound to guanine-containing oligonucleotides (see later).

DFT calculations on the electronic and vibrational absorption spectra of Ru(TAP)(TAPH)(dppz) $]^{2+}$ As indicated in the introduction, it has been proposed on the basis of modest solvent isotope effects that the photo-induced oxidation of guanine in double-stranded polydGdC might proceed by PCET. This 
isotope effect was postulated as occurring through concurrent proton transfer from guanine to cytosine upon oxidation of the G-C base-pair (equation 3). ${ }^{26}$

An isotope effect is also observed when $\left[\mathrm{Ru}(\mathrm{TAP})_{2}(\mathrm{dppz})\right]^{2+}$ oxidizes $5^{\prime}$-GMP ${ }^{12}$ and CIDNP studies with other $\left[\mathrm{Ru}(\mathrm{TAP})_{2} \mathrm{~L}^{2+}\right.$ complexes suggest that this process might proceed by PCET within the solvent cage resulting in the formation of $\mathrm{Ru}(\mathrm{TAP})(\mathrm{TAPH})(\mathrm{dppz})]^{2+}$ (equation 4). ${ }^{13-16}$

$$
\left[\operatorname{Ru}(\mathrm{TAP})_{2}(\mathrm{dppz})\right]^{2+}+\mathrm{G} \quad \rightarrow \quad\left[\operatorname{Ru}(\mathrm{TAP})\left(\mathrm{TAPH}{ }^{\bullet}\right)(\mathrm{dppz})\right]^{2+}+\mathrm{G}(-\mathrm{H})^{\bullet}
$$

We have therefore simulated the IR spectra of various isomers of $\left[\mathrm{Ru}(\mathrm{TAP})\left(\mathrm{TAPH}{ }^{\bullet}\right)(\mathrm{dppz})\right]^{2+}$ formed by protonation of the coordinated TAP radical anion both at the uncoordinated N-atoms (N1 and N8) and at $\mathrm{C}$-atoms (C3 and $\mathrm{C} 2)$. These are shown in Figure 8. The simulated spectra of the N-protonated radicals (i.e., those proposed to be intermediates in the photo-CIDNP studies of the reaction of $\left[\mathrm{Ru}(\mathrm{TAP})_{2} \mathrm{~L}^{2+}\right.$ with $\left.5^{\prime}-\mathrm{GMP}^{13-14,16}\right)$ compare poorly to the measured spectrum of the reduced $\left[\mathrm{Ru}(\mathrm{TAP})_{2}(\mathrm{dppz})\right]^{2+}$ complex produced electrochemically, while somewhat better agreement is found where the proton is on the C3 atom (Figure 8(d)).

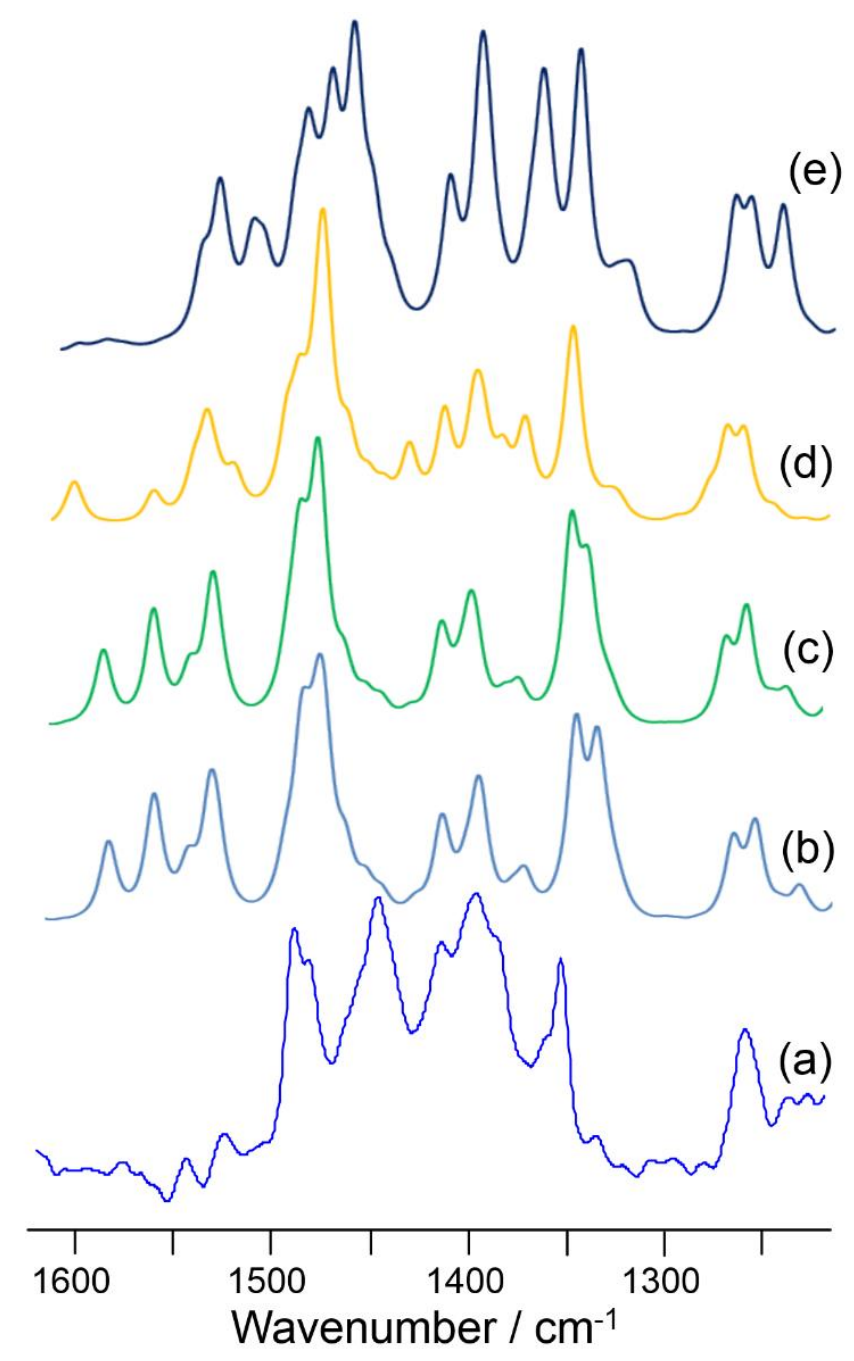

Figure 8. A comparison of the experimental IR absorption spectrum of (a) the reduced complex $\left[\mathrm{Ru}(\mathrm{TAP})_{2}(\mathrm{dppz})\right]^{+}$in acetonitrile and the simulated IR absorption spectra of [Ru(TAP)(TAPH)(dppz)] ${ }^{2+}$ protonated at (b) N1 (c) N8 (d) C3 and (e) C2 (see Figure 1 for numbering system). 
Calculation of the electronic excited states of the various $[\mathrm{Ru}(\mathrm{TAP})(\mathrm{TAPH} \bullet)(\mathrm{dppz})]^{2+}$ species was also carried out (Supporting Information Table S5). None of these calculations predict strong near-IR absorption bands in the region $>1000 \mathrm{~nm}$ in contrast to what is experimentally observed (and predicted by TD-DFT calculations, see Figure 3 ) for the one-electron reduced species $\left[\operatorname{Ru}(\mathrm{TAP})_{2}(\mathrm{dppz})^{+}\right.$(Figure 4 (d)). The UV/vis spectra of the reduced species with protons on the N1 and C3 atoms are presented in the Supporting Information Figure S7

Comparison of spectroelectrochemical data with TA and TRIR data of $\left[R u(T A P)_{2}(d p p z)\right]^{2+} /$ guanine systems

The spectro-electrochemical experiments reported here show that there are characteristic changes in the UV/vis, near-IR and mid-IR spectra following the one-electron reduction in acetonitrile. Using these spectra of $\left[\mathrm{Ru}(\mathrm{TAP})_{2}(\mathrm{dppz})\right]^{2+}$ and $\left[\mathrm{Ru}(\mathrm{TAP})_{2}(\mathrm{dppz})\right]^{+}$it is possible to generate difference spectra (Figures 9 (a) and (c)). These spectra can then be directly compared to the TA and TRIR spectra obtained for photoexcited $\left[\operatorname{Ru}(\mathrm{TAP})_{2}(\mathrm{dppz})\right]^{2+}$, which when bound to guanine-containing DNA lead to photooxidation of guanine. ${ }^{25-30}$ The yield of this photo-induced electron transfer has been shown to depend on both the enantiomer and the sequence of the DNA. ${ }^{25,27-30}$ One of the highest yielding system so far examined is that of the $\Lambda$-enantiomer intercalated in double-stranded $\mathrm{d}\left(\mathrm{G}_{5} \mathrm{C}_{5}\right) .{ }^{30}$ The TA and TRIR spectra of this system after the electron transfer process is complete are shown in Figure 9 (b) and (d). The principal features of both the TA and TRIR qualitatively reflect well those derived from the spectroelectrochemical (SEC) measurements. In both the TRIR and IR spectra of $\left[\mathrm{Ru}(\mathrm{TAP})_{2}(\mathrm{dppz})\right]^{+}$the dominating feature is a band at ca. $1460 \mathrm{~cm}^{-1}$. The latter is not present in the IR spectrum of $\left[\operatorname{Ru}(\mathrm{TAP})_{2}(\mathrm{dppz})\right]^{2+}$.
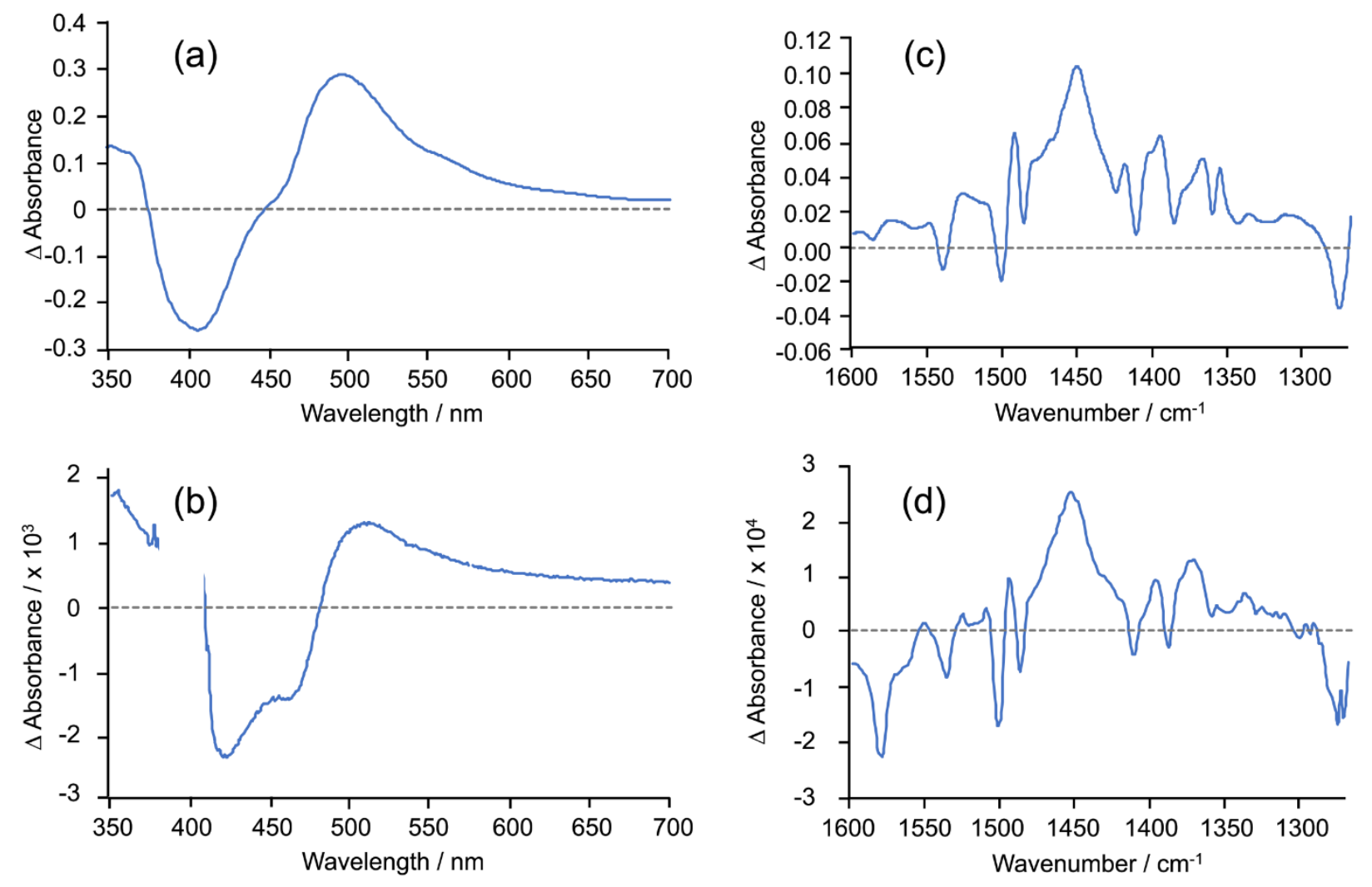

Figure 9. (a) Difference UV/vis absorption spectrum of electrochemically reduced species minus $\left[\mathrm{Ru}(\mathrm{TAP})_{2}(\mathrm{dpp} z)\right]^{2+}$ in acetonitrile- $d_{3}(\mathrm{~b})$ ps-TA spectrum of $\Lambda$-[Ru(TAP) $\left.)_{2}(\mathrm{dppz})\right]^{2+}(400 \mu \mathrm{M})$ in the presence of double- 
stranded $\mathrm{d}\left(\mathrm{G}_{5} \mathrm{C}_{5}\right)\left(500 \mu \mathrm{M}\right.$ duplex) in $\mathrm{D}_{2} \mathrm{O}$ in $50 \mathrm{mM}$ phosphate buffer $(\mathrm{pH} 7)$ recorded $1150 \mathrm{ps}$ after excitation. (The region around $400 \mathrm{~nm}$ has been removed due to pump-laser scatter, reference 30) (c) Difference IR absorption spectrum of the electrochemically reduced species minus $\left[\mathrm{Ru}(\mathrm{TAP})_{2}(\mathrm{dppz})\right]^{2+}$ in acetonitrile- $d_{3}(\mathrm{~d})$ ps-TRIR spectrum of $\Lambda$ $\left[\mathrm{Ru}(\mathrm{TAP})_{2}(\mathrm{dppz})\right]^{2+}(400 \mu \mathrm{M})$ in the presence of double-stranded $\mathrm{d}\left(\mathrm{G}_{5} \mathrm{C}_{5}\right)(500 \mu \mathrm{M}$ duplex $)$ in $\mathrm{D}_{2} \mathrm{O}$ in 50 mM phosphate buffer (pH 7) recorded 1150 ps after excitation. The prominent bleach at $1580 \mathrm{~cm}^{-1}$ is due to a guanine ring vibration, reference 30 .

As noted in the Introduction, it has been reported that the excited state of $\left[\mathrm{Ru}(\mathrm{TAP})_{2}(\mathrm{dppz})\right]^{2+}$ is efficiently quenched by 5'-GMP and nanosecond flash photolysis showed the formation of transient species expected to be $[\operatorname{Ru}(\mathrm{TAP})(\mathrm{TAPH})(\mathrm{dppz})]^{2+}$ and the guanine radical (equation 4$){ }^{12}$ Figure 10 (a) shows the TA spectra of $\left[\mathrm{Ru}(\mathrm{TAP})_{2}(\mathrm{dppz})\right]^{2+}$ in the presence of $5^{\prime}$-GMP. The excited state difference spectrum (measured at $1 \mathrm{~ns}$ after the laser pulse) shows a strong bleach signal between 390 and $510 \mathrm{~nm}$ and a weak broad absorption band with a maximum at ca. $650 \mathrm{~nm}$. The TA spectra measured at times after the reaction of the excited state (>500 ns) (see inset) are very weak compared to those observed when the complex is intercalated into the oligonucleotide and there is no strong bleach signal. This transient spectrum is in excellent agreement with that reported in the earlier nanosecond flash photolysis experiments in an argon-saturated solution. ${ }^{12}$ To further investigate this species TRIR measurements were carried out (Figure 10(b)). It may be noted that unfortunately the TRIR spectral absorption of the long-lived species in the $1300-1550 \mathrm{~cm}^{-1}$ region is weak despite averaging, preventing further detailed analysis. The low yield of the reduced ruthenium product is presumably a consequence of efficient back electron transfer within the encounter complex.

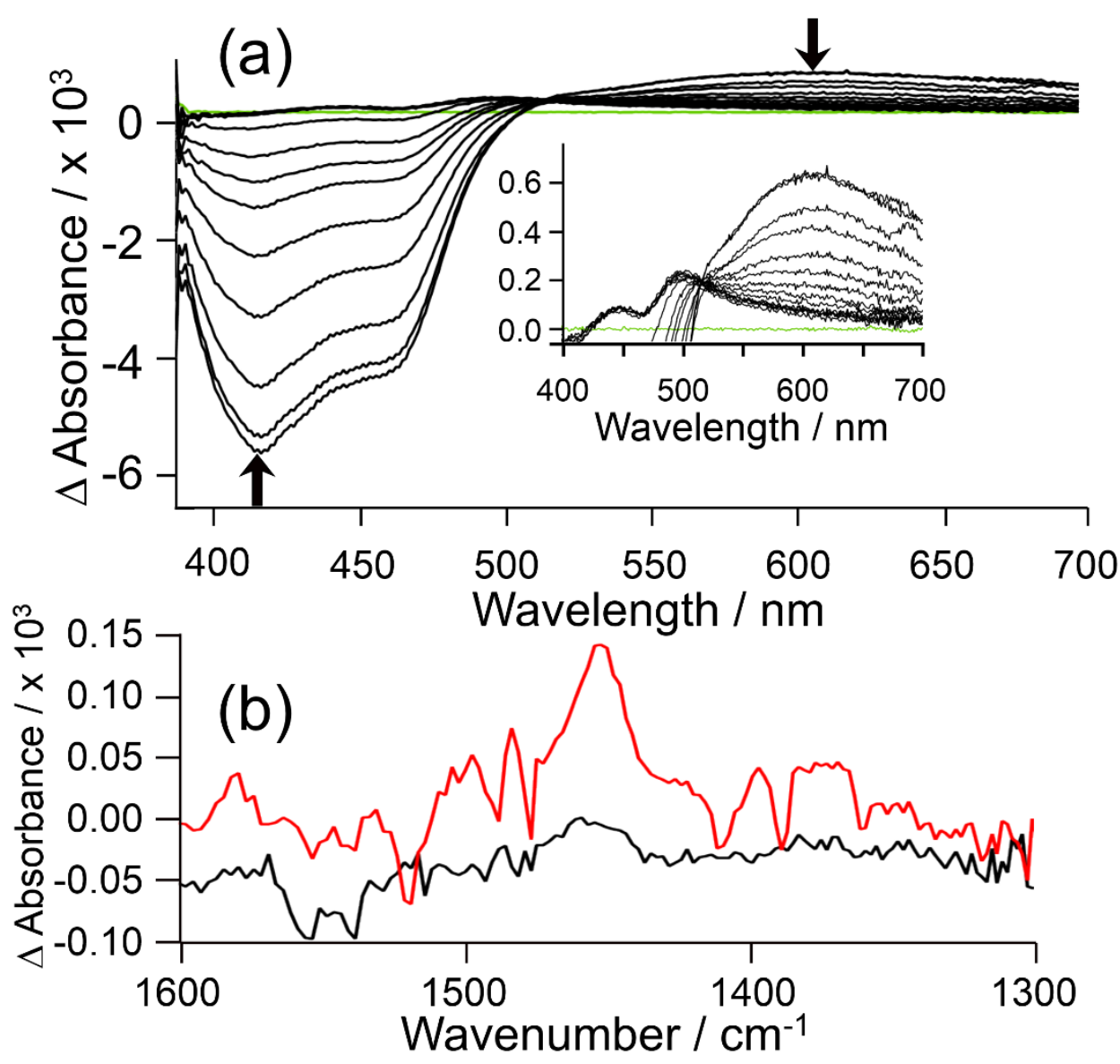

Figure 10. Transient absorption spectra of $\left[\mathrm{Ru}(\mathrm{TAP})_{2}(\mathrm{dppz})\right]^{2+}(400 \mu \mathrm{M})$ in the presence of GMP (10 mM ). (a) ns-TA spectra recorded in $50 \mathrm{mM}$ Na-phosphate buffer $\mathrm{pH} 7$ in $\mathrm{D}_{2} \mathrm{O}$ at selected delays from $1 \mathrm{~ns}$ to $10 \mu \mathrm{s}$ after the 355-nm excitation (1 $\mu$ ). (Similar results are obtained at pH 5.5) Inset: magnified view of transient region; (b) TRIR spectrum in 50 mM Na-phosphate buffer pH 5.5 in $\mathrm{D}_{2} \mathrm{O}$ ( $\lambda_{\mathrm{exc}}=400 \mathrm{~nm}, 500 \mathrm{~nJ}$.); red, average of 0.9- and 1.0-ns delay spectra; black, average of 700-and 1000-ns delay spectra. 


\section{Conclusion}

In summary, the excellent reversibility, including a very small peak-to-peak separation in the spectroelectrochemical experiments, suggest that the $1 \mathrm{e}^{-}$reduction of $\left[\mathrm{Ru}(\mathrm{TAP})_{2}(\mathrm{dppz})\right]^{2+}$ in acetonitrile proceeds by direct electron transfer. Comparison of the UV/visible and IR absorption spectra so obtained and the TA and TRIR data obtained from the photoredox reaction when $\left[\mathrm{Ru}(\mathrm{TAP})_{2}(\mathrm{dppz})\right]^{2+}$ is bound to guanine-containing DNA demonstrated that the latter process results in the formation of $\left[\mathrm{Ru}(\mathrm{TAP})_{2}(\mathrm{dppz})\right]^{+}$, probably by the mechanism shown in equation 3. DFT/TD-DFT calculations predict many of the features for the formation of this species, especially the band at $1460 \mathrm{~cm}^{-1}$ which is a strong TRIR absorption feature. By contrast, calculations of the mid-IR spectra of various isomers of $[\mathrm{Ru}(\mathrm{TAP})(\mathrm{TAPH})(\mathrm{dppz})]^{2+}$ do not predict a strong band at ca. $1460 \mathrm{~cm}^{-1}$, suggesting that this species is not formed in the photosensitized reaction with DNA. This contrasts with the PCET process proposed for the excited-state reaction with 5'-GMP, which would yield $[\mathrm{Ru}(\mathrm{TAP})(\mathrm{TAPH})(\mathrm{dppz})]^{2+}$, by analogy with related systems monitored by CIDNP. ${ }^{13-16}$ Unfortunately, the yield of the escape products is rather low so the resultant TRIR spectral absorption is very weak and cannot be used to definitively assign the nature of the reduced ruthenium complex.

A striking feature of the spectro-electrochemical investigation of $\left[\mathrm{Ru}(\mathrm{TAP})_{2}(\mathrm{dppz})\right]^{+}$is the detection of absorption bands in the near-IR region. This absorption was predicted by the TD-DFT calculations and appears to be dominantly a LMCT transition involving the reduced TAP ligand. Interestingly, similarly strong near-IR bands are also detected in the absorption spectrum of the 1,4,5,8-tetraazaphenanthrene radical anion itself. Similar near-IR absorption bands are not predicted by TD-DFT methods for protonated $[\mathrm{Ru}(\mathrm{TAP})(\mathrm{TAPH})(\mathrm{dppz})]^{2+}$, so that transient spectroscopy with near-IR monitoring should be an excellent method for distinguishing the different mechanisms.

\section{Supporting Information.}

Experimental section, extra Figures of TL-CVs, extra experimental and simulated IR spectra of the 1ereduction products of $\left[\mathrm{Ru}(\mathrm{TAP})_{2}(\mathrm{dppz})\right]^{2+}$ and of TAP, simulated IR spectra obtained using various functionals and calculated UV/vis absorption spectra of $[\mathrm{Ru}(\mathrm{TAP})(\mathrm{TAPH})(\mathrm{dppz})]^{2+}$. Extra Tables of calculated electronic states of $\left[\operatorname{Ru}(\mathrm{TAP})_{2}(\mathrm{dppz})\right]^{2+}$ and $\left[\mathrm{Ru}(\mathrm{TAP})_{2}(\mathrm{dppz})\right]^{+}$, IR absorption bands of $\left[\mathrm{Ru}(\mathrm{TAP})_{2}(\mathrm{dppz})\right]^{2+}$ and $\left[\mathrm{Ru}(\mathrm{TAP})_{2}(\mathrm{dppz})\right]^{+}$, molecular coordinate files for $\left[\mathrm{Ru}(\mathrm{TAP})_{2}(\mathrm{dppz})\right]^{2+}$, $\left[\operatorname{Ru}(\mathrm{TAP})_{2}(\mathrm{dpp} z)\right]^{+}$and $[\mathrm{Ru}(\mathrm{TAP})(\mathrm{TAPH})(\mathrm{dpp} z)]^{2+}$.

\section{Author information.}

Email addresses

F.Hartl@Reading.ac.uk,

JMKelly@tcd.ie

Conor.Long@,dcu.ie

Orcid Numbers CJC: 0000-0002-2556-9995 SJQ: 0000-0002-7773-8842 FH: 0000-0002-7013-5360, PMK: 0000-0003-2828-8512 JMK: 0000-0002-3706-1777

\section{Acknowledgements}

The spectroelectrochemical experiments were financially supported by Spectroelectrochemistry Reading (a spin-out company at the University of Reading). Samples of $\left[\mathrm{Ru}(\mathrm{TAP})_{2}(\mathrm{dppz})\right]\left(\mathrm{PF}_{6}\right)_{2}$ and TAP were kindly donated by Sandra Estalayo-Adrián, Bjorn Poulsen and Fergus Poynton, in the group of Professor Thorfinnur Gunnlaugsson. The authors wish to acknowledge the SFI/HEA Irish Centre for High-End Computing (ICHEC) for the provision of computational facilities and support. Transient spectroscopic experiments carried out at the Ultra Laboratory of the Central Laser Facility of the Rutherford Appleton 
Laboratory during the programmed access (App 13230047; BBSRC BB/K019279/1 and BB/M004635/1). JMK acknowledges financial support of the Royal Irish Academy/Royal Society Exchange Programme.

\section{References}

1. Poynton, F. E.; Bright, S. A.; Blasco, S.; Williams, D. C.; Kelly, J. M.; Gunnlaugsson, T., The development of ruthenium(II) polypyridyl complexes and conjugates for in vitro cellular and in vivo applications. Chem. Soc. Rev. 2017, 46 (24), 7706-7756.

2. Notaro, A.; Gasser, G., Monomeric and dimeric coordinatively saturated and substitutionally inert Ru(II) polypyridyl complexes as anticancer drug candidates. Chem. Soc. Rev. 2017, 46 (23), 7317-7337.

3. Heinemann, F.; Karges, J.; Gasser, G., Critical Overview of the Use of Ru(II) Polypyridyl Complexes as Photosensitizers in One-Photon and Two-Photon Photodynamic Therapy. Acc. Chem. Res. 2017, 50 (11), 27272736.

4. $\quad$ Zeng, L. L.; Gupta, P.; Chen, Y. L.; Wang, E. J.; Ji, L. N.; Chao, H.; Chen, Z. S., The development of anticancer ruthenium(II) complexes: from single molecule compounds to nanomaterials. Chem. Soc. Rev. 2017, 46 (19), 5771-5804.

5. Li, G. Y.; Sun, L. L.; Ji, L. N.; Chao, H., Ruthenium(II) complexes with dppz: from molecular photoswitch to biological applications. J. Chem. Soc., Dalton Trans. 2016, 45 (34), 13261-13276.

6. Bolze, F.; Jenni, S.; Sour, A.; Heitz, V., Molecular photosensitisers for two-photon photodynamic therapy. J. Chem. Soc., Chem. Commun. 2017, 53 (96), 12857-12877.

7. Lecomte, J. P.; Kirsch-De Mesmaeker, A.; Feeney, M. M.; Kelly, J. M., Ruthenium(II) complexes with 1,4,5,8,9,12-hexaazatriphenylene and 1,4,5,8-tetraazaphenanthrene ligands: Key role played by the photoelectron transfer in DNA cleavage and adduct formation. Inorg. Chem. 1995, 34 (26), 6481-6491.

8. Kelly, J. M.; McConnell, D. J.; Ohuigin, C.; Tossi, A. B.; Kirsch-De Mesmaeker, A.; Masschelein, A.; Nasielski, J., Ruthenium Polypyridyl Complexes - Their Interaction with DNA and Their Role as Sensitizers for its Photocleavage. J. Chem. Soc., Chem. Commun. 1987, (24), 1821-1823.

9. Lecomte, J. P.; Kirsch-De Mesmaeker, A.; Kelly, J. M.; Tossi, A. B.; Gorner, H., Photoinduced ElectronTransfer from Nucleotides to Ruthenium-tris-1,4,5,8-Tetraazaphenthrene - Model for Photosensitized DNA Oxidation. Photochem. Photobiol. 1992, 55 (5), 681-689.

10. Jacquet, L.; Davies, R. J. H.; Kirsch-De Mesmaeker, A.; Kelly, J. M., Photoaddition of $\left[\mathrm{Ru}(\operatorname{tap})_{2}(\mathrm{bpy})\right]^{2+}$ to DNA: A new mode of covalent attachment of metal complexes to duplex DNA. J. Am. Chem. Soc. 1997, 119 (49), 11763-11768.

11. Candeias, L. P.; Steenken, S., Structure and Acid-Base Properties of One-Electron-Oxidized Deoxyguanosine, Guanosine, and 1-Methyguanosine. J. Am. Chem. Soc. 1989, 111 (3), 1094-1099.

12. Ortmans, I.; Elias, B.; Kelly, J. M.; Moucheron, C.; Kirsch-De Mesmaeker, A., $\left[\operatorname{Ru}(T A P)_{2}(d p p z)\right]^{2+}$ : a DNA intercalating complex, which luminesces strongly in water and undergoes photo-induced proton-coupled electron transfer with guanosine-5 '-monophosphate. J. Chem. Soc., Dalton Trans. 2004, (4), 668-676.

13. Troian-Gautier, L.; Mugeniwabagara, E.; Fusaro, L.; Cauet, E.; Kirsch-De Mesmaeker, A.; Luhmer, M., Photo-CIDNP Reveals Different Protonation Sites Depending on the Primary Step of the Photoinduced Electron/Proton-Transfer Process with Ru(II) Polyazaaromatic Complexes. J. Am. Chem. Soc. 2017, 139 (42), 1490914912.

14. Perrier, S.; Mugeniwabagara, E.; Kirsch-De Mesmaeker, A.; Hore, P. J.; Luhmer, M., Exploring Photoreactions between Polyazaaromatic Ru(II) Complexes and Biomolecules by Chemically Induced Dynamic Nuclear Polarization Measurements. J. Am. Chem. Soc. 2009, 131 (34), 12458-12465.

15. Troian-Gautier, L.; Mugeniwabagara, E.; Fusaro, L.; Moucheron, C.; Kirsch-De Mesmaeker, A.; Luhmer, M., pH Dependence of Photoinduced Electron Transfer with [Ru(TAP) $\left.]_{3}\right]^{2+}$. Inorg. Chem. 2017, 56 (4), 1794-1803. 16. Cauet, E.; Bogatko, S.; Mugeniwabagara, E.; Fusaro, L.; Kirsch-De Mesmaeker, A.; Luhmer, M.; Vaeck, N., Density Functional Theory Interpretation of the H-1 Photo-Chemically Induced Dynamic Nuclear Polarization Enhancements Characterizing Photoreduced Polyazaaromatic Ru(II) Coordination Complexes. Inorg. Chem. 2010, 49 (17), 7826-7831. 
17. Friedman, A. E.; Chambron, J. C.; Sauvage, J. P.; Turro, N. J.; Barton, J. K., Molecular Light Switch for DNA - $\left[\mathrm{Ru}(\mathrm{Bpy})_{2}(\mathrm{Dppz})\right]^{2+}$. J. Am. Chem. Soc. 1990, 112 (12), 4960-4962.

18. McKinley, A. W.; Lincoln, P.; Tuite, E. M., Environmental effects on the photophysics of transition metal complexes with dipyrido 2,3-a:3 ',2 '-c phenazine (dppz) and related ligands. Coord. Chem. Rev. 2011, 255 (21-

22), 2676-2692.

19. Hall, J. P.; O'Sullivan, K.; Naseer, A.; Smith, J. A.; Kelly, J. M.; Cardin, C. J., Structure determination of an intercalating ruthenium dipyridophenazine complex which kinks DNA by semiintercalation of a tetraazaphenanthrene ligand. Proceedings of the National Academy of Sciences of the United States of America 2011, 108 (43), 17610-17614.

20. Niyazi, H.; Hall, J. P.; O'Sullivan, K.; Winter, G.; Sorensen, T.; Kelly, J. M.; Cardin, C. J., Crystal structures of Lambda-[Ru(phen $\left.)_{2} \mathrm{dppz}\right]^{2+}$ with oligonucleotides containing TA/TA and AT/AT steps show two intercalation modes. Nature Chem. 2012, 4 (8), 621-628.

21. Song, H.; Kaiser, J. T.; Barton, J. K., Crystal structure of Delta-[Ru(bpy $\left.)_{2} \mathrm{dppz}\right]^{2+}$ bound to mismatched DNA reveals side-by-side metalloinsertion and intercalation. Nature Chem. 2012, 4 (8), 615-620.

22. Hall, J. P.; Cook, D.; Morte, S. R.; McIntyre, P.; Buchner, K.; Beer, H.; Cardin, D. J.; Brazier, J. A.; Winter, G.; Kelly, J. M.; Cardin, C. J., X-ray Crystal Structure of fac- $\left[R u(p h e n)_{2} d p p z\right]^{2+}$ with d(ATGCAT) ${ }_{2}$ Shows Enantiomer Orientations and Water Ordering. J. Am. Chem. Soc. 2013, 135 (34), 12652-12659.

23. Hall, J. P.; Sanchez-Weatherby, J.; Alberti, C.; Quimper, C. H.; O'Sullivan, K.; Brazier, J. A.; Winter, G.; Sorensen, T.; Kelly, J. M.; Cardin, D. J.; Cardin, C. J., Controlled Dehydration of a Ruthenium Complex-DNA Crystal Induces Reversible DNA Kinking. J. Am. Chem. Soc. 2014, 136 (50), 17505-17512.

24. Hall, J. P.; Keane, P. M.; Beer, H.; Buchner, K.; Winter, G.; Sorensen, T. L.; Cardin, D. J.; Brazier, J. A.; Cardin, C. J., Delta chirality ruthenium 'light-switch' complexes can bind in the minor groove of DNA with five different binding modes. Nucleic Acids Res. 2016, 44 (19), 9472-9482.

25. Cardin, C. J.; Kelly, J. M.; Quinn, S. J., Photochemically active DNA-intercalating ruthenium and related complexes - insights by combining crystallography and transient spectroscopy. Chem. Sci. 2017, 8 (7), 47054723.

26. Elias, B.; Creely, C.; Doorley, G. W.; Feeney, M. M.; Moucheron, C.; Kirsch-De Mesmaeker, A.; Dyer, J.; Grills, D. C.; George, M. W.; Matousek, P.; Parker, A. W.; Towrie, M.; Kelly, J. M., Photooxidation of guanine by a ruthenium dipyridophenazine complex intercalated in a double-stranded polynucleotide monitored directly by picosecond visible and infrared transient absorption spectroscopy. Chem. Eur. J. 2008, 14 (1), 369-375.

27. Keane, P. M.; Poynton, F. E.; Hall, J. P.; Sazanovich, I. V.; Towrie, M.; Gunnlaugsson, T.; Quinn, S.; Cardin, C. J.; Kelly, J. M., Reversal of a Single Base-Pair Step Controls Guanine Photo-Oxidation by an Intercalating Ruthenium(II) Dipyridophenazine Complex. Angew. Chem. Int. Ed. 2015, 54, 8364-8368.

28. Keane, P. M.; Poynton, F. E.; Hall, J. P.; Clark, I. P.; Sazanovich, I. V.; Towrie, M.; Gunnlaugsson, T.; Quinn, S. J.; Cardin, C. J.; Kelly, J. M., Monitoring guanine photo-oxidation by enantiomerically resolved Ru(II) dipyridophenazine complexes using inosine-substituted oligonucleotides. Faraday Discuss. 2015, 185, 455-469. 29. Keane, P. M.; Hall, J. P.; Poynton, F. E.; Poulsen, B. C.; Gurung, S. P.; Clark, I. P.; Sazanovich, I. V.; Towrie, M.; Gunnlaugsson, T.; Quinn, S. J.; Cardin, C. J.; Kelly, J. M., Inosine Can Increase DNA's Susceptibility to Photooxidation by a Ru-II Complex due to Structural Change in the Minor Groove. Chem. Eur. J. 2017, 23 (43), 1034410351.

30. Keane, P. M.; Poynton, F. E.; Hall, J. P.; Clark, I. P.; Sazanovich, I. V.; Towrie, M.; Gunnlaugsson, T.; Quinn, S. J.; Cardin, C. J.; Kelly, J. M., Enantiomeric Conformation Controls Rate and Yield of Photoinduced Electron Transfer in DNA Sensitized by Ru(II) Dipyridophenazine Complexes. J. Phys. Chem. Lett. 2015, 6 (4), 734-738.

31. Schindler, J.; Traber, P.; Zedler, L.; Zhang, Y.; Lefebvre, J. F.; Kupfer, S.; Grafe, S.; Demeunynck, M.; Chavarot-Kerlidou, M.; Dietzek, B., Photophysics of a Ruthenium Complex with a pi-Extended Dipyridophenazine Ligand for DNA Quadruplex Labeling. J. Phys. Chem. A 2018, 122 (32), 6558-6569.

32. Daniel, C., Photochemistry and photophysics of transition metal complexes: Quantum chemistry. Coord. Chem. Rev. 2015, 282, 19-32.

33. Very, T.; Ambrosek, D.; Otsuka, M.; Gourlaouen, C.; Assfeld, X.; Monari, A.; Daniel, C., Photophysical Properties of Ruthenium(II) Polypyridyl DNA Intercalators: Effects of the Molecular Surroundings Investigated by Theory. Chem. Eur. J. 2014, 20 (40), 12901-12909. 
34. Chantzis, A.; Very, T.; Daniel, C.; Monari, A.; Assfeld, X., Theoretical evidence of photo-induced charge transfer from DNA to intercalated ruthenium (II) organometallic complexes. Chem. Phys. Lett. 2013, 578, 133137.

35. Ambrosek, D.; Loos, P. F.; Assfeld, X.; Daniel, C., A theoretical study of Ru(II) polypyridyl DNA intercalators Structure and electronic absorption spectroscopy of $\left[R u(p h e n)_{2}(d p p z)\right]^{2+}$ and $\left[R u(\operatorname{tap})_{2}(d p p z)\right]^{2+}$ complexes intercalated in guanine-cytosine base pairs. J. Inorg. Biochem. 2010, 104 (9), 893-901.

36. Coates, C. G.; Callaghan, P.; McGarvey, J. J.; Kelly, J. M.; Jacquet, L.; Kirsch-De Mesmaeker, A., Spectroscopic studies of structurally similar DNA-binding Ruthenium (II) complexes containing the dipyridophenazine ligand. J. Mol. Struct. 2001, 598 (1), 15-25.

37. Krejčík, M.; Daněk, M.; Hartl, F., Simple Construction of an Infrared Optically Transparent Thin-Layer Electrochemical-Cell - Applications to the Redox Reactions of Ferrocene, $\mathrm{Mn}_{2}(\mathrm{CO})_{10}$ and $\mathrm{Mn}(\mathrm{CO})_{3}(3,5$-Di-tertButyl-Catecholate)'. J. Electroanal. Chem. 1991, 317 (1-2), 179-187

38. Tan-Sien-Hee, L.; Kirsch-De Mesmaeker, A., Spectroelectrochemical and Flash Photochemical Reduction of 1,4,5,8-Tetraazaphenthrene and 1,4,5,8,9,12-Hexaazatriphenylene Mono- and Bi-metallic Ruthenium(II) Complexes. J. Chem. Soc., Dalton Trans. 1994, 3651-3658.

39. Soupart, A.; Alary, F.; Heully, J. L.; Elliott, P. I. P.; Dixon, I. M., Exploration of Uncharted (PES)-P-3 Territory for $\left[\mathrm{Ru}(\mathrm{bpy})_{3}\right]^{2+}$ : A New (MC)-M-3 Minimum Prone to Ligand Loss Photochemistry. Inorg. Chem. 2018, 57 (6), 3192-3196.

40. Dixon, I. M.; Heully, J. L.; Alary, F.; Elliott, P. I. P., Theoretical illumination of highly original photoreactive (MC)-M-3 states and the mechanism of the photochemistry of Ru(II) tris(bidentate) complexes. PCCP 2017, 19 (40), 27765-27778. 